Beata Karpińska-Musiał

Uniwersytet Gdański

Izabela Orchowska

Uniwersytet im. Adama Mickiewicza w Poznaniu

\title{
ŚWIADOMOŚĆ PRZEDMIOTOWA I EPISTEMOLOGICZNA NAUCZYCIELA - REFLEKSYJNEGO PRAKTYKA Z PERSPEKTYWY POLSKIEJ GLOTTODYDAKTYKI
}

\section{Disciplinary and epistemological awareness of a foreign language teacher as a reflective practitioner from the perspective of foreign language didactics in Poland}

The following article concerns the issue of educating foreign language teachers to be reflective practitioners in the Polish academic context. A starting point for our discussion is the assumption that the process of academic FL teacher education should be directed at developing the student teacher's disciplinary and epistemological awareness. The first part of the article is devoted to the concept of glottodidactics as a research area in Poland and to the evaluation of the usefulness of theories from the field of pedeutology for the formulation of a progressive model of teacher education. Next, we define the concepts of disciplinary and epistemological awareness of FL teachers, and confront them with the notion of reflective practice (Schön, 1983) and the paradigm of reflexive modernity (Beck, Giddens and Lash, 2009). Finally, we propose a preliminary model for developing both types of awareness in tertiary education, based on specific transpositions of glottodidactic knowledge into the skills needed in the field.

Key words: disciplinary awareness, epistemological awareness, FL teacher as a reflective practitioner, glottodidactic field community, reflexive modernity paradigm

Słowa kluczowe: świadomość przedmiotowa, świadomość epistemologiczna, nauczyciel JO jako refleksyjny praktyk, glottodydaktyczna wspólnota naukowa, paradygmat nowoczesności refleksyjnej 


\section{Wprowadzenie}

O ile refleksja ogólna nad poznaniem naukowym stanowi przedmiot metodologii nauk, metarefleksja nad funkcjonowaniem glottodydaktyki może być uznana za nieodłączny element jej rozwoju jako nauki autonomicznej. Jednocześnie konceptualizacja pojęć leży w podstawowej gestii językoznawstwa kognitywnego, które z glottodydaktyką łączy częściowo wspólny przedmiot badań.

Teoria kategoryzacji językowej pozwala na systematyzowanie tego, co tworzone jest w języku naturalnym, a przez to umożliwia porozumiewanie się w ramach wspólnot epistemicznych. Pozwala także na dokonywanie analiz naukowych oraz na umieszczanie w ich wyniku pojęć w ramach poszczególnych paradygmatów naukowych. Prezentowany poniżej artykuł ma na celu próbę takiego właśnie usystematyzowania pojęć świadomości przedmiotowej i epistemologicznej w obszarze polskiej glottodydaktyki oraz zaproponowanie modelowego ujęcia procesu rozwijania obu typów świadomości u nauczycieli.

\section{Koncepcja polskiej glottodydaktyki jako nauki autonomicznej a wkład pedeutologii w kształcenie nauczycieli języków obcych w Polsce}

Lata 70. i 80. XX wieku to okres wypracowywania w polskim kontekście akademickim oryginalnej koncepcji glottodydaktyki jako nauki (Grucza, 1978, 1983; Pfeiffer, 1977; Komorowska, 1982 i in.). Zaowocowało to zdefiniowaniem glottodydaktyki jako dyscypliny naukowej przede wszystkim autonomicznej, a dopiero w drugiej kolejności interdyscyplinarnej, której przedmiotem badań jest problematyka przyswajania oraz nauczania i uczenia się JO. Należy jednak pamiętać, że pod koniec lat 70. glottodydaktyka była uważana za dziedzinę samodzielną, ale tylko do pewnego stopnia, gdyż do przedmiotu jej zainteresowań, jakim był układ glottodydaktyczny, odnosiły się także dziedziny pokrewne (Grucza, 1978: 41-43).

Konsekwencje postulowanej autonomii naukowej glottodydaktyki dla sposobu definiowania teorii glottodydaktycznej oraz relacji pomiędzy teorią a praktyką dydaktyczną były w różny sposób interpretowane przez poszczególnych glottodydaktyków. Dla Bańczerowskiego (1980: 5-21) teoria glottodydaktyczna jest teorią zaksjomatyzowaną, czyli opartą na pewnych pojęciach pierwotnych przyjętych na gruncie tej nauki. Zdaniem Komorowskiej (1982: 23-25) jest ona teorią redukcyjną, co oznacza, że zawiera twierdzenia uzasadnione wiedzą zaczerpniętą z innych dziedzin. W ujęciu Gruczy (1978: 37) względnie autonomiczna glottodydaktyka powinna posiadać swój własny poziom badań/informacji czystych i stosowanych. Pfeiffer (1977) wyróżnia natomiast czteropoziomową koncepcję teorii glottodydaktycznej, obejmują- 
cą metateorię czystą i stosowaną oraz teorię czystą i stosowaną, przy czym poziom metateoretyczny obejmuje według tego autora zagadnienia dotyczące konstruowania teorii glottodydaktycznej ${ }^{1}$.

XXI wiek cechuje brak konsensusu wewnątrz polskiej wspólnoty glottodydaktycznej ${ }^{2}$ zarówno w odniesieniu do nazwy dyscypliny zajmującej się nauczaniem i uczeniem się JO, jak i sposobu jej definiowania i rozumienia jej interdyscyplinarności. W konsekwencji w polskim kontekście akademickim funkcjonują obok siebie takie nazwy i koncepcje dyscypliny, jak metodyka nauczania JO, skoncentrowana na celach prakseologicznych (Komorowska, 1999), językoznawstwo stosowane (Niżegorodcew, 2009: 7-16) - termin, który całkowicie uzależnia interesującą nas dziedzinę od lingwistyki i podważa jej autonomię naukową, oraz glottodydaktyka jako nauka autonomiczna i interdyscyplinarna (Dakowska, 2010; Wilczyńska, 2010). Naszym zdaniem to właśnie z perspektywy tej ostatniej koncepcji glottodydaktyki, najbardziej zbliżonej do tego, co polscy glottodydaktycy wypracowali w latach 70. i 80. XX w., powinien zostać zdefiniowany współczesny model kształcenia nauczycieli JO.

\section{1. $O$ relacji pomiędzy glottodydaktyką a pedagogiką w perspektywie modeli kształcenia nauczycieli języków obcych}

Kształcenie kadry nauczającej to jeden z obszarów badawczych glottodydaktyki (Wilczyńska \& Michońska-Stadnik, 2010: 55). Jednak modele kształcenia nauczycieli zostały wypracowane w polskiej humanistyce przede wszystkim na gruncie badań pedagogicznych, czego przykładem jest modułowa koncep-

\footnotetext{
${ }^{1}$ Kwestia rozumienia pojęcia teoria glottodydaktyczna oraz związków między poziomem teorii i poziomem badań empirycznych w glottodydaktyce została podjęta m.in. w publikacji Dakowskiej (1987). Wzorem tej autorki (Dakowska, 1987), w niniejszym artykule, będziemy się odwoływać do koncepcji teorii glottodydaktycznej jako wypracowanej na gruncie glottodydaktyki, przyjmując jednocześnie, że wszelkiemu odwoływaniu się do teorii z nauk pokrewnych w ramach refleksji nad nauczaniem-uczeniem się JO powinna towarzyszyć ich adaptacja do specyfiki naukowej glottodydaktyki a zatem m.in. uwzględnienie specyfiki kształcenia językowego.

${ }^{2}$ Odnosimy się tutaj do terminu wspólnoty naukowej zdefiniowanego przez Kuhna (1962), przyjmując jednak, że m.in. ze względu na złożoność przedmiotu badań glottodydaktycznych trudno wewnątrz wspólnoty glottodydaktycznej mówić o jednym, wspólnym dla wszystkich jej członków paradygmacie poznawczym czy metodologicznym. Jednocześnie zakładamy, że istnienie wielu koncepcji i ujęć wewnątrz tej wspólnoty nie powinno wykluczać możliwości osiągnięcia konsensusu między glottodydaktykami, co do specyfiki epistemologicznej ich dyscypliny odniesienia oraz jej pola badawczego (Orchowska, 2013a i b).
} 
cja pedagogiczna wypracowana przez Kotusiewicz i Kwiatkowską (Kwiatkowska, 1997). Warto tutaj również zauważyć, że np. Zawadzka (2004b) zwraca uwagę na fakt, iż w praktyce, w tradycyjnym kształceniu nauczycieli na studiach neofilologicznych w Polsce nie uwzględnia się specyfiki kształcenia językowego, a prezentowane studentom teorie z zakresu pedagogiki i psychologii, ze względu na ich niezorientowaną glottodydaktycznie selekcję, nie mają na ogół bezpośredniego związku z nauczaniem-uczeniem się JO.

Tymczasem, jak twierdzi Wysocka (2003: 11), specyfika dydaktyki szczegółowej JO jest tak różna od dydaktyki szczegółowej każdego innego przedmiotu, że stawia ona przed nauczycielami określone wymagania ukierunkowane na rozwijanie ich kompetencji zawodowej, obejmującej zespół poglądów i umiejętności mających charakter wysoce interdyscyplinarny. Zestaw tak rozumianych umiejętności sięga do założeń glottodydaktyki, ale także pedagogiki, psychologii, językoznawstwa ogólnego, gramatyki opisowej, psycho- i socjolingwistyki, literatury, historii i cywilizacji danego obszaru językowego oraz praktycznej nauki języka specjalizacji.

Zważywszy na powyższe, naszym zdaniem w sytuacji kształcenia nauczycieli JO odwoływanie się do koncepcji pedagogicznych, takich jak np. wspomniana przez nas modułowa koncepcja pedagogiczna (Kwiatkowska, 1997), powinno oznaczać m.in. rozwijanie świadomości studentów w zakresie specyfiki procesu glottodydaktycznego (świadomości przedmiotowej), a także jego interpretacji natury metodologicznej i epistemologicznej (świadomości epistemologicznej). Tym dwóm rodzajom świadomości poświęcimy dalszą część naszego artykułu.

\section{2. $O$ indywidualnych teoriach nauczycieli z perspektywy glottodydaktyki}

Jak zauważył Polak (1999: 12), badania pedeutologiczne nad nauczycielskim myśleniem o procesach edukacyjnych mają wpływ nie tylko na cele procesu kształcenia nauczycieli, jego treść, czy wykorzystane metody, lecz także na modelowanie systemu edukacyjnego jako całości. Jednocześnie $w$ tle dokonujących się przemian społecznych i ekonomicznych zmieniają się cel i charakter badań pedeutologicznych, szczególnie w przypadku badań teorii indywidualnych ${ }^{3}$, co

\footnotetext{
${ }^{3}$ Teorie indywidualne, nazywane w literaturze glottodydaktycznej również teoriami subiektywnymi to „zbiór osobistych doświadczeń (także wyuczonych schematów lekcji), wiedzy, doświadczeń innych, stereotypów i uprzedzeń wynikających z obserwacji i nastawień oraz zbiór postaw dotyczących zarówno uczenia się i nauczania, jak i uczniów i samych siebie" (Zawadzka, 2004a: 105). Jak zauważa Michońska-Stadnik (2013: 31), teorie osobiste kontrastują z teoriami naukowymi, które są z kolei formalne, logiczne, spójne i jednorodne, nie są identyfikowane z wartościami i opisują związki przyczynowo-skutkowe.
} 
ilustruje m.in. fakt, że rzeczą pierwszej wagi staje się odkrywanie i wyjaśnianie tego, jak nauczyciel rozumie proces kształcenia i wychowania, a nie szukanie cech tzw. efektywnego nauczyciela. W sferze paradygmatów naukowych, funkcjonujących w pedeutologii, oznacza to, że dominującą pozycję zajmują badania o charakterze konstruktywistycznym, które koncentrują się na odkrywaniu, w jaki sposób nauczyciele konstruują sensy i jakie znaczenie nadają poszczególnym elementom sytuacji dydaktyczno-wychowawczych (Polak, 1999: 13).

W kontekście naszej refleksji, osadzonej naukowo w obszarze glottodydaktyki, konieczne jest podjęcie próby odpowiedzi na pytanie, czy i w jaki sposób badania pedeutologiczne, koncentrujące się na specyficznych konstrukcjach poznawczych nauczyciela, mogą być wykorzystane w kształceniu nauczycieli języków obcych. To wyzwanie natury epistemologicznej wymaga wcześniejszego ustosunkowania się do interdyscyplinarnego charakteru badań nad edukacją, a przede wszystkim zdefiniowania specyfiki relacji pomiędzy glottodydaktyką a pedeutologią jako subdyscypliną pedagogiczną. W takiej interdyscyplinarnej koncepcji kształcenia nauczycieli, rozwijanie świadomości przedmiotowej i epistemologicznej nauczycieli i przyszłych nauczycieli języków obcych nabiera kluczowego znaczenia.

\section{3. Świadomość przedmiotowa i epistemologiczna wobec koncepcji refleksyjnej praktyki i paradygmatu nowoczesności refleksyjnej}

Pojęcie świadomości jest pojęciem wieloznacznym. W glottodydaktyce stanowi ono przede wszystkim kategorię rozważań w obrębie relacji pomiędzy autonomią i teorią kognitywnego uczenia się, a określane jest jako świadomość językowa ucznia (Myczko, 2004: 22). Jest także związane z koncepcją uwrażliwiania na język, która została rozwinięta w latach 70. XX wieku i opiera się na założeniu, że proces uczenia się może być wspierany poprzez świadome podejście do języka, którego się uczymy. Również w publikacjach glottodydaktycznych dotyczących kształcenia nauczycieli języków obcych, pojęcie świadomości językowej, a szczególnie jej komponentów, jakimi są świadomość metajęzykoznawcza (Stalmaszczyk, 2008; Karpińska-Musiał, 2009), oraz świadomość i wrażliwość interkulturowa (Orchowska, 2008) są wymieniane wśród zestawu kompetencji nauczycielskich.

\subsection{Pojęcie świadomości przedmiotowej}

Pojęcie świadomości przedmiotowej zostało zdefiniowane w kontekście badań prowadzonych we Francji i ukierunkowanych na rozwijanie świadomości 
aktorów procesu kształcenia na poziomie szkoły podstawowej i szkoły średniej. Pojęcie to odnosi się do sposobu, w jaki aktorzy społeczni, a dokładniej aktorzy szkolni, (re)konstruują dyscypliny rozumiane jako przedmioty szkolne (Reuter, 2007: 59). Świadomość ta dotyczy więc nie tylko uczniów, ale także nauczycieli, kadry kształcącej (przyszłych) nauczycieli, kuratorów i badaczy. Reuter wyróżnia cztery przestrzenie w ramach takiej (re)konstrukcji: przestrzeń przepisów (poprzez dokumenty oficjalne), przestrzeń zaleceń (poprzez kształcenie nauczycieli, podręczniki, działalność stowarzyszeń), przestrzeń wyobrażeń aktorów procesu nauczania i uczenia się i przestrzeń działań praktycznych. W konsekwencji przejawami świadomości przedmiotowej są opanowane w wysokim stopniu treści kształcenia i nauczania oraz sposoby ich prezentowania w klasie przez osoby nauczające. Strykowski (2005: 17) określa tego typu świadomość kompetencjami merytorycznymi, a np. Dylak (1995: 38-41) przytacza w ramach kompetencji koniecznych - kompetencje realizacyjne, interpretacyjne i autokreacyjne. Dla nauczycieli języków obcych oznacza to przede wszystkim doskonałą wiedzę z zakresu przedmiotu, popartą umiejętnościami jej aplikacji, przekazania oraz egzekwowania.

\subsection{Pojęcie świadomości epistemologicznej}

Według Wilczyńskiej i Michońskiej-Stadnik (2010: 72) istnieją spore rozbieżności między poszczególnymi członkami polskiej wspólnoty badaczy specjalizujących się w glottodydaktyce i to „zarówno jeśli chodzi o poziom ich wtajemniczenia w dany zakres wiedzy, jak i ich biegłość metodologiczną". Towarzyszy temu - jak twierdzą cytowane powyżej autorki - niewystarczający stan świadomości i umiejętności metodologicznych sporej części polskich glottodydaktyków, wynikający w dużej mierze z braku konsensusu, co do wspólnej definicji glottodydaktyki oraz zakresu jej badań. Taki stan świadomości wewnątrz polskiej wspólnoty glottodydaktycznej przemawia za koniecznością uwzględnienia w procesie kształcenia nauczycieli JO, a także badaczy interesującej nas dziedziny, z którymi ci pierwsi powinni współpracować m.in. w ramach glottodydaktycznych badań empirycznych, dodatkowego celu, jakim byłoby postulowane w tym artykule rozwijanie, oprócz wspomnianej już świadomości przedmiotowej, także świadomości epistemologicznej. Ta ostatnia stanowi jeden z warunków aktywnej przynależności glottodydaktyków do glottodydaktycznej wspólnoty naukowej (Orchowska, 2013a), nawet jeśli w przypadku większości nauczycieli ich rola wewnątrz takiej wspólnoty będzie się często ograniczała do bycia odbiorcą publikacji naukowych na temat nauczania i uczenia się JO.

$\mathrm{Na}$ tym polu szczególnej uwagi wymaga charakter związku pomiędzy nauczycielem praktykiem a badaczem oraz poziom refleksji potrzebny obojgu 
do prowadzenia skutecznej dydaktyki. Dakowska (2010: 11-12), konfrontując ze sobą nauczanie JO jako sferę działalności praktycznej z nauczaniem JO jako przedmiotem dziedziny naukowej, zauważa, że nie należy tych sfer działania utożsamiać ze sobą, nawet jeśli są one sobie niezbędnie potrzebne. Nauczyciele bowiem wykorzystują w trakcie swojej praktyki zawodowej wiedzę wypracowaną przez naukowców, ale nie mają obowiązku konstruowania ogólnych modeli i wyjaśniających teorii akwizycji językowej, ani też testowania wynikających z nich hipotez. Zawadzka (2004a: 100) zwraca natomiast uwagę na fakt, że szczególną rolę w ocenie przydatności teorii w pracy zawodowej nauczyciela JO odgrywa wciąż charakterystyczne dla tradycyjnego myślenia edukacyjnego i wyniesione z nauk przyrodniczych przekonanie, że teorie i badania naukowe odzwierciedlają rzeczywistość edukacyjną poprzez dostarczanie pewnych i niezawodnych reguł działania dydaktycznego. Koncepcja ta wynika z przeniesionego na edukację scjentystycznego obrazu świata, zakładającego zgodność przyczynowo-skutkową, której konsekwencją jest przekonanie, że wystarczy wiedzieć, aby działać prawidłowo i że teoria powinna być bezpośrednio przedmiotem wdrożenia. Ten pozytywistyczny paradygmat powinien w modelach kształcenia nauczycieli ustąpić miejsca paradygmatowi humanistycznemu, w którym wiedza teoretyczna powinna być traktowana ,jjako droga humanistycznego poznania, jako sposób nabywania sprawności w interpretowaniu złożonej rzeczywistości edukacyjnej" (Zawadzka, 2004a: 102). Dominujący w jego efekcie interpretatywizm znajduje odzwierciedlenie $w$ wiekszysci nauk humanistycznych i powinien być również uwzględniony w glottodydaktyce.

Reasumując, nauczyciel o rozwiniętej świadomości epistemologicznej będzie zdawał sobie sprawę ze swoich osobistych teorii na temat procesu nauczania i uczenia się JO, dostrzeże ich ograniczenia, a tym samym zdoła wypracować u siebie postawę otwartości w stosunku do odmiennych poglądów oraz poznawanych teorii naukowych. Poza tym, świadomość tego, czym jest teoria glottodydaktyczna rozpatrywana na poziomie metapoznawczym i tego, jak należy się do niej odnosić w procesie interpretowania praktyki dydaktycznej, pozwoli nauczycielowi wyzbyć się nieadekwatnych oczekiwań w stosunku do teorii i pojęć naukowych, a także lepiej zrozumieć, jak wiedza teoretyczna jest konstruowana przez naukowców. Dzięki temu lektura publikacji naukowych przez nauczycieli, będąca nieodłącznym elementem ich kształcenia i samokształcenia, może stanowić dla nich nie tylko okazję do poszerzania własnej wiedzy teoretycznej, ale przede wszystkim impuls do zdynamizowania własnych wyobrażeń i postaw w tym zakresie. Tym samym będzie przeciwdziałać rutynie, która blokuje refleksję na działaniem. Wreszcie, w toku ciągłego i dynamicznego poznawania uwarunkowań procesu na- 
uczania i uczenia się JO, nauczyciel o rozbudowanej świadomości epistemologicznej będzie potrafił korzystać również z osiągnięć nauk pokrewnych glottodydaktyce, przy jednoczesnym uwzględnieniu specyfiki kształcenia językowego. Oznacza to, że taki nauczyciel, biorąc pod uwagę np. osiągnięcia językoznawstwa w zakresie definiowania takich pojęć, jak język, dyskurs czy komunikacja, będzie definiował przedmiot procesu przyswajania JO nie jako abstrakcyjny system, ale jako repertuar zindywidualizowanych, a jednocześnie społecznie osadzonych praktyk dyskursywnych i z perspektywy takiego ujęcia będzie definiował cele nauczania. Jest to ogromnie ważne w interpretowaniu złożoności procesu glottodydaktycznego i warunkuje, naszym zdaniem, funkcjonowanie nauczyciela jako refleksyjnego praktyka.

\subsection{Nauczyciel jako refleksyjny praktyk, czyli poziom meta $w$ rozwijaniu obu typów świadomości nauczycieli Jo}

Pojęcie refleksyjnego praktyka wywodzi się z badań anglosaskich opartych na założeniu, że integralnym elementem pracy profesjonalistów z wielu dziedzin jest nieustanna refleksja w działaniu (Schön, 1983: 138). Schön zaproponował nowy rozdział epistemologii w zakresie kształcenia zawodowego, przyjmując, że znajomość czegoś objawia się w działaniu, w interakcji z otoczeniem i polega na zdolności zmagania się z problemem na bazie wykorzystania wiedzy, której nie jest się świadomym. Naszym zdaniem, o ile nauczyciele JO powinni być wdrażani do refleksyjnej praktyki, to proces ich kształcenia powinien obejmować również poziom metarefleksji nad ową praktyką. Zasadniczą rolę w konstruowaniu obu świadomości odgrywa sposób, w jaki nauczyciele i przyszli nauczyciele języków obcych interpretują i korzystają z dostępnej im wiedzy. Jak zauważa na gruncie glottodydaktyki Zawadzka (2004a: 104), jedynie otwarta na różnorodność interpretacji, krytyczna i niedogmatyczna postawa nauczyciela stworzy podstawę do umiejętnego korzystania z teorii zarówno naukowych, jak i osobistych.

Refleksja to „,proces intelektualny, polegający na strukturyzacji bądź restrukturyzacji doświadczenia, własnej wiedzy, czy nawet intuicji" (Kwiatkowska, 1997: 146). Jednocześnie, w ujęciu Schöna (1983), nie należy sprowadzać praktyki jedynie do wdrożenia teorii, a refleksja nie jest jedynie stosowaniem teorii naukowej w działaniu praktycznym. Profesjonalista uczy się rozpoznawać, definiować i ponownie definiować konkretne sytuacje, sprawdza różne interpretacje problemów i na tej podstawie modyfikuje działania. Poza tym odnosi się on nie tyle do wiedzy naukowej, ile do wiedzy konstruowanej podczas działania i rekonstruowanej z doświadczenia. 
W przeciwieństwie do Schöna uważamy jednak, że nie należy negować znaczącej roli wiedzy naukowej w interpretowaniu przez nauczycieli całości układu glottodydaktycznego. Taka interpretacja jest z kolei warunkowana tym, że osoby nauczające JO będą świadome specyfiki teorii glottodydaktycznej, że nie będą jej rozumiały jako zbioru uniwersalnych rozwiązań trudności obserwowanych w procesie nauczania i uczenia językowego, ale wypracują na jej bazie własne, kreatywne nastawienie do współkonstruowanych przy swoim udziale sytuacji edukacyjnych. Należy bowiem pamiętać, że w swoim działaniu pedagogicznym nauczyciel bardzo rzadko rozwiązuje problemy identyczne z tymi, z jakimi zetknął się wcześniej i dlatego współczesny profesjonalizm nauczyciela to nie tyle skrupulatność w praktycznym stosowaniu z góry przyjętych teorii, ile radzenie sobie z takimi sytuacjami pedagogicznymi, które cechuje niepewność i unikatowość (Kwiatkowska, 1997: 70-71). Doskonale tłumaczy to zjawisko coraz bardziej ugruntowany w naukach społecznych paradygmat zmiany (Fullan, 1993), a także współobecny w obszarze nauk humanistycznych i społecznych paradygmat tzw. nowoczesności refleksyjnej (Lash, 2009: 146).

\section{Wpływ paradygmatu nowoczesności refleksyjnej na kształcenie nauczycieli Jo}

Nowoczesność (modernizacja) refleksyjna, tak jak przedstawia ją Lash, jest paradygmatem odbiegającym od promowania istniejących struktur nowoczesnych, w których anonimowość była wartością przez to, że uwolniła się od sztywnych struktur kolektywnych na rzecz autonomizacji i upodmiotowienia (Lash, 2009: 146). Przekładając to na rzeczywistość dydaktyczną współczesnych nauczycieli, nowoczesność postulowała autonomię rozumianą jako przede wszystkim indywidualizację nauczania i uczenia się. Paradygmat refleksyjny natomiast podkreśla wagę umożliwiania podejmowania autonomicznych decyzji w dydaktyce także wtedy, gdy oznaczają one chęć wejścia w nowe relacje kolektywne (uczenie się nauczycieli wzajemne, w działaniu, feedback ze strony środowiska, autoewaluacja). Słowem kluczem jest tutaj jednak świadomość własnych decyzji, refleksja nad ich konsekwencjami i w pełni autonomiczne uwolnienie się od jakichkolwiek struktur „z nadania społecznego”, rozumianych jako działania narzucone przez system szkolnictwa lub kształcenia wyższego.

Warto zastanowić się teraz nad tym, jakie konkretne działania dydaktyczne mogą przyczynić się do budowania postulowanych przez nas dwóch rodzajów świadomości u przyszłych (ale także praktykujących już) nauczycieli JO, przy jednoczesnym rozwijaniu ich podejścia refleksyjnego. Mogłyby one, zgodnie z omówionymi założeniami i tłem teoretycznym, opierać się na dyna- 
micznych transpozycjach, których przykładowe ujęcie przedstawia Tabela 1. Ze względu na istniejące w dyskusji nad narzędziami ewaluacji dydaktyki pojęcia wiedzy, umiejętności i postaw, proponujemy spojrzenie na ewoluowanie świadomości nauczycieli od przedmiotowej po epistemologiczną przez pryzmat transpozycji wiedzy w umiejętności i tychże w postawy. Analogicznie traktujemy więc świadomość epistemologiczną jako kumulację wiedzy i umiejętności, realizowanych dzięki określonym postawom wobec wykonywania własnej działalności zawodowej i badawczej. Zestawienie to jest oczywiście syntetyczne i ograniczone do kilku przykładów w zakresie wiedzy glottodydaktycznej (tj. metod nauczania, podejścia interkulturowego w nauczaniu i uczeniu się JO, dydaktyki autonomizującej i interdyscyplinarności w glottodydaktyce) oraz odpowiadających im umiejętności i postaw. Nie rozwijamy w nim wszystkich ważnych dla glottodydaktyki zagadnień, takich jak np. samo pojęcie kompetencji komunikacyjnej i jej komponentów jako przedmiotu nauczania i uczenia się oraz jako przedmiotu badań glottodydaktycznych, czy kwestii oceniania i testowania, gdyż przede wszystkim chcemy w sposób kompaktowy uwypuklić procesualny charakter rozwijania złożonych kompetencji nauczycieli JO.

I tak, znajomość metod nauczania języka docelowego traktujemy jako poznawczą podstawę świadomości przedmiotowej nauczyciela JO. Rozwinięte w modelowanym przez nas procesie kształcenia umiejętności selekcjonowania stosownych metod w zależności od kontekstu, grupy oraz możliwości odbiorcy tworzą trzon świadomości przedmiotowej i umożliwiają zarazem wypracowanie postawy otwartości i elastyczności w ich stosowaniu. Postawa ta pozwala na przejście na kolejny etap świadomości, bliższy już świadomości epistemologicznej, a oparty na wiedzy naukowej o strategiach uczenia się i zasadach dydaktyki autonomizującej. Innymi słowy, o ile świadomość przedmiotowa ogranicza się do wiedzy i umiejętności metodycznych, o tyle świadomość epistemologiczna budowana jest na bazie naukowych teorii glottodydaktycznych oraz teorii wypracowanych na gruncie nauk pokrewnych (m.in. pedagogiki, psychologii, nauk o komunikacji czy antropologii kulturowej) i zaadoptowanych do specyfiki procesu glottodydaktycznego. To właśnie wiedza na temat nauczania-uczenia się JO o charakterze naukowym pozwala osobie nauczającej na diagnozowanie grupy jej uczniów pod kątem różnorodności stosowanych przez nich strategii uczenia się oraz przy uwzględnieniu ich wyobrażeń na temat nauczanego przedmiotu i dzięki temu sprzyja autonomizacji uczniów w procesie rozwijania ich kompetencji komunikacyjnej i uczeniowej. Wiedza i umiejętności, o których mowa powyżej są oczywiście ściśle związane z postawami przyszłych i już aktywnych zawodowo nauczycieli. W przypadku współpracy pomiędzy nimi a ich uczniami w ramach praktykowania dydaktyki 
autonomizującej nie do przeceniania jest empatia osób nauczających w odbiorze zachowań i postaw uczniów, wzmocniona wiedzą o ich teoretycznym podłożu.

Trzeci proponowany przez nas element, nieodłącznie związany z poprzednimi dwoma, a także je warunkujący, to wiedza na temat interdyscyplinarności glottodydaktyki jako nauki. Nie można posiąść umiejętności diagnostycznych bez znajomości psychologii rozwoju człowieka (zwłaszcza jeśli uczniem jest dziecko), tak jak i nie można rozumieć trudności w uczeniu się (czy też wspierać uczniów zdolnych) bez wiedzy z zakresu pedagogiki. Stąd akceptację interdyscyplinarności glottodydaktyki uznajemy za postawę należącą już do zakresu świadomości epistemologicznej.

I w końcu, w zakresie podejścia interkulturowego, którego stosowanie w procesie nauczania-uczenia się JO aktywuje zarówno sferę świadomości przedmiotowej, jak i sferę świadomości epistemologicznej osób nauczających, konieczne jest rozwijanie u studentów jako przyszłych nauczycieli szerokiego zakresu umiejętności z obszaru wiedzy przedmiotowej, oraz kluczowych kompetencji społecznych, a zwłaszcza postawy otwartości i wrażliwości na inność. Ta sztuka wejścia na poziom agonistycznej relacji z Innym, nie tylko w wymiarze filozoficznym, ale także czysto pragmatycznym, wydaje się być kluczowym warunkiem do wejścia na poziom epistemologicznej świadomości nauczyciela JO jako refleksyjnego praktyka.

\begin{tabular}{|c|c|c|c|}
\hline \multirow[t]{2}{*}{ PRZEDMIOT } & \multicolumn{3}{|c|}{ 1. TRANSPOZYCJA } \\
\hline & WIEDZA - Treść & UMIEJĘTNOŚCI - Efekt & POSTAWY-Efekt \\
\hline \multirow[t]{3}{*}{$\begin{array}{l}\text { Dydaktyka } \\
\text { języków obcych } \\
\text { (glotto- } \\
\text { dydaktyka) }\end{array}$} & $\begin{array}{l}\text { przegląd metod } \\
\text { nauczania }\end{array}$ & $\begin{array}{l}\text { umiejętność selekcji i świado- } \\
\text { mego wyboru stosownych } \\
\text { metod dostosowanych do } \\
\text { kontekstu kształcenia (świa- } \\
\text { domość przedmiotowa); }\end{array}$ & $\begin{array}{l}\text { otwartość na różnorodnośćć } \\
\text { metod pracy i elastyczność } \\
\text { w ocenie ich efektywności; }\end{array}$ \\
\hline & $\begin{array}{l}\text { przegląd strategii } \\
\text { uczenia się - dydak- } \\
\text { tyka autonomizująca }\end{array}$ & $\begin{array}{l}\text { umiejętność diagnozowania } \\
\text { strategii obieranych przez } \\
\text { uczniów i uwzględnianie } \\
\text { indywidualizacji w nauczaniu } \\
\text { i uczeniu się JO (świadomość } \\
\text { przedmiotowa i epistemolo- } \\
\text { giczna); }\end{array}$ & $\begin{array}{l}\text { wrażliwość na indywidual- } \\
\text { ne cechy ucznia, empatia } \\
\text { w odbiorze zachowań } \\
\text { i postaw uczniów; }\end{array}$ \\
\hline & $\begin{array}{l}\text { interdyscyplinarność } \\
\text { glottodydaktyki jako } \\
\text { nauki }\end{array}$ & \begin{tabular}{|l|} 
umiejętność definiowania \\
problemów w procesie N/U JO \\
z perspektywy glottodydak- \\
tycznej przy uwzględnieniu \\
wiedzy z obszaru nauk po- \\
krewnych, tj. językoznawstwo,
\end{tabular} & \begin{tabular}{|l} 
akceptacja \\
interdyscyplinarności \\
glottodydaktyki i gotowość \\
do ukierunkowanego \\
wykorzystywania wiedzy \\
z obszaru nauk pokrew-
\end{tabular} \\
\hline
\end{tabular}




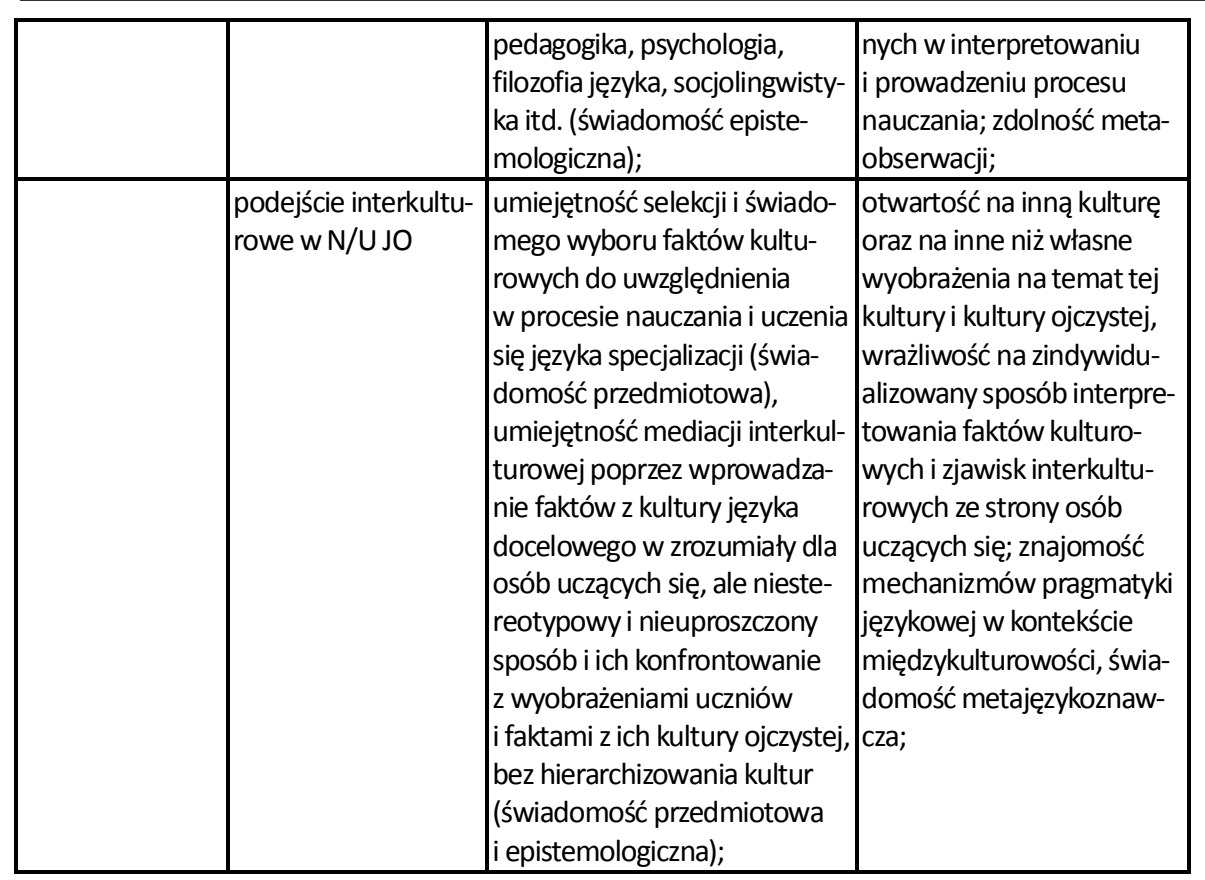

Tabela 1: Modelowe ujęcie procesu rozwijania świadomości przedmiotowej i epistemologicznej oparte o transpozycje wiedzy w umiejętności i umiejętności w postawy w zakresie glottodydaktyki.

\section{Uwagi końcowe}

Kończąc naszą refleksję, pragniemy jeszcze raz podkreślić komplementarny charakter wiedzy naukowej i osobistej nauczycieli, i stwierdzić, że o ile świadomość przedmiotowa mogłaby być uznana za główny motor rozwoju wiedzy, umiejętności i postaw glottodydaktyka jako praktyka, to świadomość epistemologiczna stanowi podstawę rozwoju jego myślenia krytycznego i jego kompetencji metodologicznych jako badacza. Należałoby to oczywiście uwzględnić w wizji progresji odnoszącej się do rozwijania obu typów świadomości. Zważywszy na fakt, że na etapie formułowania celów ogólnych kształcenia mamy ciągle do czynienia z wieloznacznością i nieokreślonością, warunkiem operacyjności obu pojęć w procesie kształcenia nauczycieli JO jest zaproponowanie obserwowalnych i mierzalnych przejawów świadomości przedmiotowej i epistemologicznej na poszczególnych etapach ich edukowania i w różnych kontekstach ich działalności zawodowej oraz badawczej. Pozwoliłoby to na wypracowanie glottodydaktycznego modelu kształcenia nauczycieli o kompleksowym charakterze. Model taki uwzględniałby z jednej strony poznawczą i metodolo- 
Świadomość przedmiotowa i epistemologiczna nauczyciela - refleksyjnego...

giczną specyfikę glottodydaktyki jako nauki, z drugiej strony również praktyczną rolę nauczyciela JO w procesie glottodydaktycznym.

\section{BIBLIOGRAFIA}

Bańczerowski, J. 1980. „A proposal for a metalanguage of glottodidactics”. Glotttodidactica XIII: 5-21.

Beck, U., A. Giddens i S. Lash. 2009. Modernizacja refleksyjna. Polityka, tradycja i estetyka w porzq̨ku społecznym nowoczesności. Warszawa: PWN.

Dakowska, M. 1987. „Czym jest a czym nie jest teoria glottodydaktyczna”. Przegląd glottodydaktyczny 8: 7-17.

Dakowska, M. 2010. „W poszukiwaniu wiedzy praktycznie użytecznej. O dojrzewaniu glottodydaktyki jako dziedziny akademickiej". Neofilolog 34: 9-19.

Dylak, S. 1995. Wizualizacja kształtowania nauczycieli. Poznań: Wyd. UAM.

Fullan, M. 1993. „The complexity of the change process” (w:) Change Forces: Probing the Depth of Educational Reform. London: Falmer Press: 19-41. http://www.pers onal.psu.edu/wxh139/Fullan.htm DW 23.10.2013.

Grucza, F. 1978. „Glottodydaktyka, jej zakres i problemy”. Przeglqd Glottodydaktyczny 1: 29-43.

Grucza, F. 1983. Zagadnienia metalingwistyki. Lingwistyka-jej przedmiot, lingwistyka stosowana. Warszawa: PWN.

Karpińska-Musiał, B. 2009. „Treść, rola i pozycja wiedzy metajęzykoznawczej w kształceniu kompetencji międzykulturowej glottodydaktyków" (w:) Komunikacja społeczna w edukacji: inspiracje, analizy, działania. (red. M. Nowak-Dziemianowicz, K. Czerwiński i W. J. Maliszewski). Toruń: Adam Marszałek. 263-289.

Komorowska, H. 1982. Metody badań empirycznych w glottodydaktyce. Warszawa: PWN. Komorowska, H. 1999. Metodyka nauczania języków obcych. Warszawa: WSiP.

Kuhn. T., 1962. The Structure of Scientific Revolutions. Chicago: University of Chicago Press. Kwiatkowska, H. 1997. Edukacja nauczycieli. Konteksty-kategorie - praktyki. Warszawa: IBE.

Lash, S. 2009. „Refleksyjność i jej sobowtóry: struktura, estetyka, wspólnota” (w:) Modernizacja refleksyjna. Polityka, tradycja i estetyka w porzqdku społecznym nowoczesności (red. U. Beck, A. Giddens i S. Lash). Warszawa: PWN: 145-221.

Michońska-Stadnik, A. 2013. Teoretyczne i praktyczne podstawy weryfikacji wybranych teorii subiektywnych w kształceniu nauczycieli języków obcych. Wrocław: Wydawnictwo Uniwersytetu Wrocławskiego.

Myczko, K. 2004. „Kognitywna teoria uczenia się i rozwijanie autonomii ucznia w dydaktyce języków obcych" (w:) Autonomia w nauce języka obcego (red. M. Pawlak). Poznań - Kalisz: Wydawnictwo UAM: 19-30.

Niżegorodcew, A. 2009. „Dwie tradycje badawcze w językoznawstwie stosowanym dotyczącym języka drugiego". Neofilolog 34: 7-16.

Orchowska, I. 2008. La formation interculturelle des futurs enseignants de FLE dans le contexte universitaire polonais. Kraków: Flair. 
Orchowska, I. 2013a. „O rozbieżnościach konceptualnych w definiowaniu zakresu obszaru badawczego wewnątrz wspólnoty naukowej polskich glottodydaktyków” (w:) Poznańskie Spotkania Językoznawcze, tom 26: Od wspólnot komunikatywnych do kontaktów międzywspólnotowych (red. P. Nowakowski, K. Stroński i M. Szczyszek). Poznań: Wydawnictwo Polskiego Towarzystwa Przyjaciół Nauk: 61-77.

Orchowska, I. 2013b. „De la communication spécialisée à l'intérieur de la communauté glottodidactique polonaise. Conceptualisation de l'objet de la discipline et de son interdisciplinarité" (w:) From Classroom to Workplace: Advances in Applied Linguistics (red. E. Wąsikiewicz-Firley i H. Lankiewicz). Piła: PWSZ w Pile: 189-206.

Pfeiffer, M. 1977. „Toward a theory of glottodidactics: Some methodological remarks”. Kwartalnik Neofilologiczny 24: 361-367.

Polak, K. 1999. Indywidualne teorie nauczycieli. Kraków: Wydawnictwo UJ.

Reuter, Y. 2007. „La conscience disciplinaire. Présentation d'un concept”. Education et didactique, vol. 1 (2): 55-71.

Schön, D. 1983. The Reflective Practitioner. How Professionals Think in Action. London: Temple Smith.

Stalmaszczyk, P. 2008. „Językoznawcze i dydaktyczne aspekty uświadomionej wiedzy językowej" (w:) Językoznawstwo a dydaktyka języków obcych. Teoria i praktyka (red. J. Florczak i M. Gajos). Warszawa: Wydawnictwo Piktor: 13-12.

Strykowski, W. 2005. „Kompetencje współczesnego nauczyciela”. Neodidagmata 27/28:15-28.

Wilczyńska, W. 2010. „Obszary badawcze glottodydaktyki”. Neofilolog 34: 21-35.

Wilczyńska, W. i A. Michońska-Stadnik. 2010. Metodologia badań w glottodydaktyce. Wprowadzenie. Kraków: Avalon/Flair.

Wysocka, M. 2003. Profesjonalizm w nauczaniu języków obcych. Katowice: Wydawnictwo Uniwersytetu Śląskiego.

Zawadzka, E. 2004a. Nauczyciele języków obcych w dobie przemian. Kraków: Impuls.

Zawadzka, E. 2004b. „Integracja w nauczaniu języków obcych - zarys problematyki”. Neofilolog 24: 6-13. 